\title{
THE CONCEPT OF QUDWAH HASANAH AND MUSLIM WOMEN'S ROLES IN THE STRENGTHENING OF THE UMMAH: AN ANALYSIS OF RECENT MALAY NOVELS
}

\author{
Kamariah Kamarudin \\ kkamaria@upm.edu.my
}

Faculty of Modern Languages and Communication Universiti Putra Malaysia

\section{Abstract}

In the contex of Islam, the concept of qudwah hasanah, that is, a good example or model, is not only applicable to men but also to women in society. Qudwah hasanah is important, for one, because it helps to strengthen the family institution, and the ummah as a whole. In line with this, women are equally responsible for realizing qudwah hasanah, especially since women are considered to be "educators" by nature. In many works of Malay literature in this country, Muslim women are presented as the central figures around which these works revolve. A great number of female characters in these works are shown to have exemplary characteristics. Because of this, the present study aims to examine the characteristics of qudwah hasanah in relation to the female characters in several recent Malay novels published by women authors, namely Baromkeh Matamu di Mataku (Baromkeh: Seeing Through Your Eyes) by Ummu Hani Abu Hassan, Seteguh Fikrah Saleha (As Strong as Saleha's Thought) by Aminah Mokhtar, Delima Ranting Senja (The Pomegranate of the Evening Branch) by Siti Zainon Ismail, Episod Cinta di Tanah Hijrah (Love in the Land of Migration) by Amaruszati Noor Rahim, and Lentera Mustika (Mustika's Lantern) by Nisah Haron. This study also examines the extent to which local women authors are able to create female Muslim characters in line with the concept of qudwah hasanah.

Keywords: qudwah hasanah, Muslim women, ummah, Malay novels 


\section{INTRODUCTION}

Women writers and Malay literature have a relatively long relationship, which can be traced back to the publication of Bulan Melayu in 1930, in Johor Bahru. This magazine became the showcase for early women writers in Malay literature. In fact, it has been said that Bulan Melayu was an important publication as it allowed Malay women to express their ambitions in life, especially in the fields of education, teaching, and culture, both in a nationalistic and religious manner. ${ }^{1}$ Therefore, it can be said the relationship between writing and women in Malay literature, where the expression of women's attitudes are concerned, is one that has existed for a long time. It has also had some impact on the relationship between women authors and their degree of achievement in writing. A great number of women writers can be seen to present dominant women characters in their writings. By placing female characters at the centre of their work, it can be seen that these women authors also raise the status of such women. This is in agreement with the Islamic point of view that women, just like men, are the best of Allah's creations. The Qur'an clearly states this special status in more than one surah (chapter) and ayah (verse), among them surah al-Furqan ayah 54, surah Fatir ayah 11, surah al-Nisa' ayah 32, surah al-Nisa' ayah 124, surah al-Baqarah ayah 187, and surah al-Hujurat ayah 13. In fact, the elevated status of Muslim women is further explained in the biography of the Prophet and several other studies. ${ }^{2}$

Based on the translation of the verses of the Qur'an and the stories of several exemplary women in the history of Islam, it is clear that women occupy a lofty and honourable position. Women are not merely the complementers of men in the sense of being wives, home-makers, mothers and the like, but have a far greater task than this. Women are said to be the movers when it comes to the strengthening of a balanced ummah in terms of this life and the next. In fact, women are tasked with aiding men in carrying the burden as qawwamun (protectors and maintainers) and daraja (degree) ${ }^{3}$ in order to create a united society. Bearing this in mind, this study concerns itself with five recently-published Malay novels written by five local women novelists. These are Delima Ranting Senja (The Pomegranate of the Evening Branch) (Siti Zainon Ismail, Utusan Publications \& Distributors Sdn. Bhd, 2009), Episod Cinta di Tanah Hijrah (Love in the Land of Migration) (Amaruszati Noor Rahim, Dewan Bahasa dan Pustaka, 2009), Lentera Mustika (Mustika's Lantern) (Nisah Haron, PTS Milenia, 2009), Seteguh Fikrah Saleha (As Strong as Saleha's Thought) (Aminah Mokhtar, PTS Publications \& Distributors Sdn. 
Bhd, 2008) and Baromkeh Matamu di Mataku (Baromkeh: Seeing Through Your Eyes) (Ummu Hani Abu Hassan, Utusan Publications \& Distributors Sdn. Bhd, 2008). It can be seen that these authors present women characters as the central characters in their plots, and send the message that women must be more visible, whether in terms of religion, personality, or in their careers, families and society. This study examines the importance of qudwah hasanah among women as the central value towards strengthening madaniyah (material progress) and hadarah (civilization), especially when it comes to creating insan al-Kamil (perfect beings). ${ }^{4}$

\section{THE CONCEPT OF QUDWAH HASANAH IN ISLAM}

The term qudwah hasanah is an Arabic phrase meaning "good example" or "good model". In terms of language, the root word for qudwah is the verb qada which can be translated to mean "exemplary". The root word for hasanah is hasuna which means "beautiful". In the Qur'an, however, it appears that qudwah is not used to mean "example" or "model". Even in the hadith (sayings) of the Prophet SAW the word is not found. In fact, the Qur'anic term for the same concept is uswah. ${ }^{5}$ The term uswah which is synonymous with qudwah is used three times in two different surah. ${ }^{6}$ The words of Allah SWT in surah al-Ahzab, ayah 21 in which the word appears can be translated to mean "There has certainly been for you in the Messenger of Allah an excellent pattern for anyone whose hope is in Allah and the Last Day and (who) remembers Allah often." In the hadith of the Prophet SAW, again the term uswah is used to mean example or model, as can be seen in the hadith which can be translated as follows:

\footnotetext{
"A man will be brought on the Day of Resurrection and thrown in the (Hell) Fire, so that his intestines will come out, and he will go around like a donkey goes around a millstone. The people of (Hell) Fire will gather around him and say: O so-and-so! What is wrong with you? Didn't you use to order us to do good deeds and forbid us to do bad deeds? He will reply: Yes, I used to order you to do good deeds, but I did not do them myself, and I used to forbid you to do bad deeds, yet I used to do them myself."
}

(Hadith recorded by Bukhari).

It is clear from the above explanation that the term qudwah refers to an example or model to be followed by others. Apart from this, qudwah is of two types, qudwah hasanah (a good example) and qudwah sayyiah (a 
bad example). In fact, the Prophet SAW is the most perfect example to be followed by all Muslims. This is due to the fact that he was given the most honourable character as befits his status as an example for all humankind. Therefore, human beings should make the Prophet SAW their example in all aspects of life. All Muslims, be they male or female, have been entrusted by Allah SWT. with becoming His vicegerents on Earth, and thus they should strive to be good examples to other people. Therefore, the present study seeks to examine the extent to which Muslim women characters portrayed by the above named women authors can in fact be taken to be qudwah hasanah.

\section{WOMEN AND THE CONCEPT OF QUDWAH HASANAH IN ISLAM}

In Islam, the concept of qudwah hasanah has an important link to Muslim women, because women are by nature "educators". Women who are wives and mothers have a great responsibility to educate their children when it comes to learning about life in this world. This can be backed up with a hadith of the Prophet SAW: "If someone has three daughters and is patient with them and clothes them from his wealth, they will be a shield against the Fire for him." (Hadith recorded by Muslim). There is another hadith recorded by Bukhari and Muslim which can also be linked to the role of women and mothers as educators: "Narrated Abu Hurairah: Allah's Apostle said, "No child is born except on Al-Fitra (Islam) and then his parents make him Jewish, Christian or Magian, as an animal produces a perfect young animal." Ayah 15 of surah al-Ahqaf also mentions the importance of women in the family institution, and that children should appreciate their mothers and the hardship that their mothers have faced: "And We have enjoined upon man, to his parents, good treatment. His mother carried him with hardship and gave birth to him with hardship..."

In fact, women were created by Allah SWT to be the companions of men, with whom they share the responsibility of being Allah's vicegerents on Earth. There are a number of Qur'anic verses that deal directly with women, while one entire surah is dedicated to issues concerning women, i.e. surah an-Nisa' - an-Nisa' meaning "women." In fact the responsibility of creating a society that fully applies and appreciates Islam is the combined responsibility of both Muslim men and Muslim women. This is stated in surah al-Taubah, ayat 71 which can be translated as "The believing men and women are allies of one another. They enjoin what is right and forbid what is wrong and establish prayer and give zakah and obey Allah and His 
Messenger. Those-Allah will have mercy upon them. Indeed, Allah is exalted in Might, and Wise."

The responsibility of bringing forth an Islamic society is closely linked to the realization of qudwah hasanah in the female individual. Therefore, a Muslimah should have the following characteristics:

1. have iman (faith);

2. possess akhlaq (good character);

3. ihsan (doing good);

4. adhere to the principles of $u k h u w a h$ (brotherhood);

5. appreciate the concept of shura (consultation);

6. always work in mutual agreement and in cooperation;

7. have tolerance;

8. be accepting of other people's points of view;

9. be shaja'ah (courageous). ${ }^{8}$

With the praiseworthy characteristics mentioned above, women can become exemplary individuals who shape society. This will lead to a strengthening of the ummah as women are capable of facing these challenging times. ${ }^{9}$ Therefore, this analysis of the concept of qudwah hasanah in these recently-published Malay novels is guided by the honourable character as promoted in Islam based on the Qur'anic ayah and the hadith previously mentioned.

\section{THE CONCEPT OF QUDWAH HASANAH IN RECENTLY-PUBLISHED MALAY NOVELS}

On the whole, recent Malay novels written by women auhors such as Siti Zainon Ismail, Amaruszati Noor Rahim, Nisah Haron, Aminah Mokhtar and Ummu Hani Abu Hassan deal with issues concerning women. These authors, who are well-known locally, may be of different generations but appear to have the same aims in presenting women as the main characters in their works. For example in Delima Ranting Senja by Siti Zainon Ismail, the main character is Sofina; in Episod Cinta di Tanah Hijrah, written by Amaruszati Noor Rahim, the main characters are the twins Maisarah and Masita; Nisah Haron's Lentera Mustika has as its central character Ainur Mustika; Seteguh Fikrah Saleha by Aminah Mokhtar showcases a character named Saleha while in Ummu Hani Abu Hassan's Baromkeh Matamu di 
Mataku is dominated by three women characters: Fahda Nur, Salwana and Iman.

In these five novels, the women characters are not only the central characters around which the issues and conflicts of the novels revolve, they are also examples of women who are honourable beings and who convey a positive message, particularly to Muslim women. The positive values found in these novels is in line with the concept of qudwah hasanah in Islam, the complete religion. The common themes are Muslim women and religion, Muslim women and their selves, Muslim women and their families, Muslim women and careers and Muslim women and society, all of which bring to the fore the honourable personalities of the characters. The ideal characteristics of a Muslimah are then also linked to five main issues in life. Therefore, this study will focus on these five main issues which are closely associated with Muslim women, especially women with these characteristics.

\section{Muslim Women and Religion}

The relationship between a Muslim woman and religion is one aspect of her existence as a khalifah (vicegerent) of Allah SWT, the Lord of Creation. Such Muslim women obey Islamic teachings and avoid whatever is forbidden. A Muslim woman should do following:

1. be diligent in worship;

2. observe all five daily obligatory prayers;

3. perform the solah (prayer) at the mosque from time to time;

4. attend the Idul Fitri dan Idul Adha prayers;

5. perform the rawatib dan nawafil sunnah prayers;

6. improve her practice of prayer;

7. pay zakat (poor-tax) for her assets;

8. perform the fast during Ramadan and Qiyamullail;

9. do the supplementary sunnah fast;

10. perform the hajj;

11. be covered with the prescribed hijab (headgear);

12. not be freely associating with men;

13. not shake hands with strange men;

14. not be travelling without a mahram (permissible guardian);

15. be accepting of fate as ordained by Allah;

16. seek Allah's forgiveness; 
17. be responsible towards her family;

18. aim to live her life for the pleasure of Allah;

19. realize the true meaning of being a worshipper of Allah;

20. promote the religion of Allah;

21. possess izzah (might, power) because of her personality and her faith;

22. enslave herself to Allah alone;

23. amar ma'ruf dan nahi mungkar (enjoin good and forbid evil);

24. read the Qur'an often. ${ }^{10}$

All this is stated in many surah in the Qur'an. Among them is surah Ali 'Imran, ayah 14 which can be translated to mean: "Beautified for people is the love of that which they desire - of women and son, heaped-up sums of gold and silver, fine branded horses, and cattle and tilled land. That is the enjoyment of worldly life but Allah has with Him the best return." Apart from this, surah an-Nisaa', ayah 32 also mentions women in an ayah that can be translated as follows: "And do not wish for that by which Allah has made some of you exceed others. For men is a share of what they have earned, and for women is a share of what they have earned. And ask Allah of his bounty. Indeed, Allah is ever, of all things, Knowing."

Surah al-Ahzab, ayah 35 can be translated as meaning: "Indeed, the Muslim men and Muslim women, the believing men and the believing women, the obedient men and the obedient women, the humble men and the humble women, the charitable men and the charitable women, the fasting men and the fasting women, the men who guard their private parts and the women who do so, and the men who remember Allah often and the women who do so-for them Allah has prepared forgiveness and a great reward." Apart from this, surah al-Mu'min (Ghafir), ayah 40 says: "Whoever does an evil deed will not be recompensed except by the like thereof; but whoever does righteousness, whether male or female, while he is a believer - those will enter Paradise, being given provision therein without account." Other mentions made of women and their roles in religion can be found in the Qur'an in surah an-Nahl, ayah 97, ${ }^{11}$ surah an-Nisaa', ayah $1^{12}$ and surah alHujuraat, ayah $13 .{ }^{13}$ In the novel Delima Ranting Senja, the author presents readers with Sofina, a female character who dominates the whole work with her personality as a defender of truth, in line with Islamic requirements. Sofina, as depicted by the author, Siti Zainon, is a woman whose adherence to religion is seen in her diligence in performing the solah (Muslim prayer) and performing the minor pilgrimage to the Holy Land even though she is 
faced with struggles in her career as a journalist, which leaves her little time. This can be seen in the following excerpt:

"Selesai seminar di Bonn, kita cuba dapatkan tiket dari Frankfurt langsung ke Jeddah. Harap direstui Ilahi, umrah di bulan Ramadhan ini alangkah indahnya."

("After the seminar in Bonn, let's get tickets directly from Frankfurt to Jeddah. Hopefully we will receive Allah's blessings for it, because in this month of Ramadhan, performing the umrah is a beautiful experience.")

(Delima Ranting Senja, 2008:2)

A similar depiction is made by the author of Episod Cinta di Tanah Hijrah. Maisarah and Masitah are characters who are both depicted as possessing a warrior spirit which puts religion above all else, and who strive to practice Islamic requirements. The twins strongly protect their honour as believing women when it comes to dealing with men. However, although each of them has a sweetheart (for Maisarah it is Tanaka, while Masitah is in love with Eng), the author does not depict their relationships in an intimate and detailed manner. This is clearly to show that they possess praiseworthy personalities as Muslim women, as required in Islam. The praiseworthy characters of the twins, who mostly deal with their sweethearts on the phone, can be observed in the following excerpt:

...Aku kembali melihat skrin Nokia. Tanaka lagi. Wajah keanak-anakan lelaki Jepun itu bergayutan di mata. Senyum dari seulas bibir comelnya seperti meminta aku menyambut panggilannya.

"Mai."

Aku diam. Di mana lelaki itu kini?

"Saya di Haadyai. Kenapa tidak datang? Mr. Zulfik dan Winson beritahu, awak tidak sihat. Kenapa?"

Aku terpana mendengar patah-patah kalimat itu. Aku tidak sihat?

"Awak sakit, Mai?'

"Err...i...ia."

"Sakit apa?"

Dadaku sebak tiba-tiba. Rahang terasa bergerak-gerak menahan hiba. Jangan menangis, jangan. Akal mengingatkan.

(...I looked at the Nokia screen once more. Tanaka again. In my mind's eye, I could see the child-like face of the Japanese man. His cute smile seemed to beg me to answer his call.

"Mai." 
I kept silent. Where was he right now?

"I'm in Haadyai. Why didn't you come? Mr. Zulfik and Winson told me you are not well. What's up?"

I was taken aback at his words. Me, not well?

"Are you sick, Mai?'

"Err...y...yes."

"What's wrong?"

Sadness suddenly welled up in my chest. My jaw began quivering. Don't, don't cry, I told myself.)

(Episod Cinta di Tanah Hijrah, 2009:25)

Another writer who tells the story of an exemplary character is Nisah Haron, who, in her novel Lentera Mustika, depicts Ainur Mustika as a Muslim woman who holds fast to the correct etiquette and guards her honour even though she is in love with Syed Amirul Hakim. This novel shows the strength of mind of Ainur Mustika as a Malay Muslim woman who conducts herself carefully in her interactions with men in order to safeguard her reputation as a university lecturer. The author depicts Ainur Mustika as an educator with a strong sense of ethics, as she mostly interacts through the telephone and text messaging service. The author foregrounds the character's propriety as a woman in the way she deals with the amorous advances of men, even though she is considered to be an "old maid". Ainur Mustika is shown as calm as she deals with her impending arranged marriage to Emir Johan, even though she has been close friends and even in love with Syed Amirul Hakim. She displays the characteristics of a woman who submits to the fate ordained by Allah SWT. In acting in this manner, she shows herself to be a Muslim woman of great character, as can be seen below:

\section{Suara Emir Johan itu benar-benar mengejutkan!}

Suara itu tidak pernah diduga. Ainur Mustika mencantumkan kembali fragmen yang telah terbentuk. Pantun dalam bentuk SMS yang singgah di telefon bimbitnya; bicara Badariah yang memberitahunya bahawa orang yang menjadi penaja penerbangannya ke Shanghai pernah berguru dengannya.

"Bagaimana, mahu membalas pantun saya?"

Ainur Mustika masih terkedu. Dia tidak tahu di mana dia harus memulakannya. Emir Johan bukanlah insan yang dalam senarai telahannya.

(Emir Johan's voice was really startling!

It was an unexpected voice. Ainur Mustika tried to put together the fragments that had formed. The poem in the SMS that had been sent to her 
phone; Badariah telling her that the person who had sponsored her trip had once been her student.

"How now, don't you want to send a reply to my poem?"

Ainur Mustika was still stunned. She did not know how to begin. Emir Johan was not someone who was on her list of expectations.)

(Lentera Mustika, 2009:131)

In her turn, Aminah Mokhtar, in her novel Seteguh Fikrah Saleha, presents a strong character-Saleha, who dominates the entire work - as a young person with an honourable character. Saleha displays the seriousness of a courageous woman who defends the dignity of her family and herself from being trampled underfoot by other people. The author depicts Saleha as someone who is decisive, courageous and patient in adhering to the principle of enjoining good and avoiding evil in dealing with family issues, even though she has to face her uncle, the arrogant and ruthless Pak Long Syawal, who wants to gain the family's land for himself. The manner in which Saleha confides in Allah SWT in every prayer, supplication and remembrance of Him, shows her to be a Muslim woman of exalted character. This can be seen in the excerpt below:

Aku panjatkan doa dalam solat sunat tasbih siang hari dan solat sunat taubat, pujuk lara dan kumpulkan kembali harapan yang patah.

Aku kunyah daun-daun semangat dengan selawat as-Syifa. Perlahanlahan kusapukan ke luka.

Ya hayyu ya qayyum. Ya zal jalali wal-ikram. La haula wala quwwata illa billahil azim.

[I appended supplications to the sunnah tasbih prayers (prayers for glorification of Allah), and the sunnah prayers for repentance that I performed, to repair my shattered hopes.

As I recited the salawat ash-Shifa (blessings for healing) it was as if I was chewing the leaves of strength, and slowly applying them to my wounds.

Ya hayyu ya qayyum. Ya zal jalali wal-ikram. La haula wala quwwata illa billahil azim.]

(Seteguh Fikrah Saleha, 2008:41)

The same can be seen in Ummu Hani Abu Hassan's novel, Baromkeh Matamu di Mataku which also revolves around a resilient woman, Fahda 
Nur, who determinedly guards her good character even when she is far from home. Her decisiveness, courage and tenacity in her struggle to uphold the high level of knowledge shows her to be an exceptional Muslim woman. Even though this young woman faces off against her own father as he tries to get her to abandon her studies and leave Syria, Fahda Nur does not submit to fatigue and instead turns to Allah. In this, she shows herself to be a Muslim woman of fortitude who should be taken as an example, especially by young people. Fahda Nur's patient and resilient character can be seen in the following excerpt, where she deals with the problems she faces with her father through worship:

...Hati mendidih perit. Seketika bertarung nafsu amarah, dia beristighfar lalu bergegas ke bilik air untuk berwuduk. Berdoa agar amarahnya dapat dipadamkan dengan air yang menyejukkan.

(...Internally, she was at a boiling point. While battling her instinct for rage, she recited words of repentance, and rushed to the bathroom to take ablution. She prayed that the fire of her anger would be put out with the cool water.)

(Baromkeh Matamu di Mataku, 2008:107)

\section{The Muslim Woman and Her Self}

The relationship of the Muslim woman with her self is a relationship that is guided by the requirements of religion. There are three things that need to be given attention: her body (whereby she is to be moderate in consumption of food and drink, to have a liking for exercise, to have a clean body and wear clean clothes, to observe good oral hygiene, to maintain the beauty of her hair, and to be physically attractive but not to adorn herself excessively to the extent that she attracts the eyes of strange men), her mind (whereby it should be filled with knowledge that is obligatory to her as a Muslim woman, and through which she is to master all knowledge, and be free of superstitions, while always reading), and her spirituality (whereby she should be diligent in performing ibadah (worship) purifying her soul, to surround herself with companions of good character, to always attend religious get-togethers, and to strive to increase her remembrance of Him and supplications to Him). ${ }^{14}$

This is mentioned in several surah in the Qur'an. For example surah alBaqarah, ayah 148, which can be translated as meaning: "For each (religious following) is a direction toward which it faces. So race to (all that is) good. Wherever you may be, Allah will bring you forth (for judgement) all together. 
Indeed, Allah is over all things competent." Apart from this, surah Ali' Imran, ayah 114, whose meaning can be rendered as: "They believe in Allah and the Last Day, and they enjoin what is right and forbid what is wrong and hasten to good deeds. And those are among the righteous."

Thus, in the novel Delima Ranting Senja, the author has devised several women characters who diligently share knowledge among one another in order to make themselves better Muslims. This can be observed in the characters of Sofina, Lolani, Datin Mariani, as well as others who keenly attend conferences and seminars about women and current issues. Such a depiction of a love for knowledge, readiness to share views, courageous expression of ideas where truth and justice are concerned are evidence that this novel showcases the role of women and the responsibility towards their self in bringing about qudwah hasanah in society. Such a depiction can be found in the following extract:

"Sudah dihuraikan dalam kertas seminar saya. Datin juga setuju bukan? Bila wanita dengan kerjaya yang difahami suaminya, kita tidak saling mencurigai. Kita boleh bergerak ke mana-mana saja berlandaskan disiplin, mengenal peribadi sekeliling, membentuk kepercayaan diri dengan landas, Allah Maha Mengetahui dan Maha Penentu. Dan manusia harus berani menerima anugerah, walaupun anugerah itu masih berupa ujian besar..."

("This has been explained in the paper I presented. You do agree, Datin, don't you? When husbands understand their wives' careers, there will be no suspicion. We could go anywhere, being guided by discipline, being aware of the nature of our surroundings, and through building self-awareness on the basis that Allah knows all and Allah is the All-Ordaining. Human beings should be courageous enough to accept any divine gift, even if it is in the form of a tough trial ...")

(Delima Ranting Senja, 2008:17)

Something similar can be found in the novel Episod Cinta di Tanah Hijrah, where Maisarah and Masitah, who consistently strive to improve themselves through the acquisition of knowledge. The twins possess a strong fighting spirit when it comes to advancing their education, leading them to be successful in life; Maisarah becomes an entrepreneur and Masitah becomes a gynaecologist. The efforts of these two young women is to contribute to the advancement of their society, not merely themselves or their family, in everything. That the author tries to promote this idea can be seen below: 
MALAY LITERATURE VOLUME 26 NUMBER 2

Aku selalu mengingatkan pesakit-pesakitku, tubuh badan ialah anugerah yang perlu dijaga semenjak lahir hingga ke nafas terakhir. Dengan jasad yang sihat, dapat bekerja dengan baik untuk mengejar prestasi di dunia. Dapat pula beribadat untuk menyempurnakan tuntutan akhirat.

(I always reminded my patients that the body is a gift that needs to be taken care of from birth to the last breath. With a healthy body, we can work well to achieve prestige in this world. We can also perform worship to fulfil our needs for the afterlife.)

(Episod Cinta di Tanah Hijrah, 2009:28)

...Selesai solat subuh, aku membaca buku. Itulah satu-satunya hobiku yang sama dengan Masitah. (terfikir juga aku, dalam kesibukan Masitah mengubati dan menyelamatkan nyawa manusia, adakah lagi waktu untuk membaca). Sebelum ke ladang, aku menyapu lantai dan membasuh pinggan. Kalau masih punya waktu, aku akan membantu mak ibu menjemur ikan. Meskipun industri ladang itu adalah kepunyaanku, aku mengikut jadual yang tetap setiap hari. Hidup perlu ada disiplin. Pengurusan waktu amat penting.

[...After the dawn prayer, I would do some reading. That was the only hobby I shared with Masitah. (I began thinking, even with her hectic schedule treating patients, Masitah still had time to read). Before going off to the plantation, I would sweep the floor and wash the dishes. If there was time, I would help mum to lay the fish out to dry. Even though the plantation was my own, I followed this schedule every day. In life, one needs to be disciplined. Time management is of the utmost importance.]

(Episod Cinta di Tanah Hijrah, 2009:104)

The novel Lentera Mustika on the other hand depicts Ainur Mustika as someone who sticks to her principles as a highly-educated person. Although she is already a university lecturer, Ainur continues to make an effort to gain a higher level of knowledge. This can be seen when Ainur tries to combine literature with law and religion, which in turn displays her willingness to look into other fields of knowledge in order to improve herself as a university lecturer. This can be seen in the following example:

“...Projek melestarikan pantun ini akan saya libat dengan pelajar kita sendiri, mereka juga wajar dibayar dengan sedikit imbuhan, atau jika tidak pun diberi insentif makan dan minum. Begitu juga dengan cetakan poster, pembelian alat tulis dan sebagainya. Ia projek sosiobudaya. Sedangkan penyelidikan saya tentunya bersifat akademik dan menggabungkan kerjasama daripada 
Fakulti Undang-undang. ,

(..."The project to preserve traditional poems will involve our own students, and they deserve a small payment for their involvement, or at least to be given free food and drink. We also need to print posters and buy stationery and such. This is a socio-cultural project. While my research may be academic in nature, the Law Faculty can contribute to it.")

(Lentera Mustika, 2009: 41)

A similar issue is presented by Aminah Mokhtar in Seteguh Fikrah Saleha where Saleha is depicted as someone with a tenacity for seeking knowledge. Armed with a strong fighting spirit, Saleha is shown as someone who continuously strives to apply whatever she has learnt at university in her life as an farming entrepreneur in her village. Saleha's diligent pursuit of knowledge can be seen in the following example:

Aku rasa sangat teruja dan luar biasa semangatnya. Minda rasa luas terbuka, bertambah yakin, diri berasa bertambah-tambah aktif, daya kreativiti semakin meningkat. Setiap projek dan perancangan yang aku bincangkan bersama Hamzah benar-benar menyeronokkan dan begitu mencabar. Diri berasa dimotivasikan dengan kejayaan-kejayaan yang sudah mula kami nikmati.

(I was excited and exceptionally enthusiastic. My mind felt open to new things, I had more confidence, felt more energetic, and my creativity seemed to increase. Each project and plan that I discussed with Hamzah was truly enjoyable and challenging. I felt completely motivated by the successes we had already achieved.)

(Seteguh Fikrah Saleha, 2008:198)

The novel Baromkeh Matamu di Mataku in turn deals with the love of its central character, Fahda Nur, towards knowledge. Even though the young woman has several times failed in her examinations, she continues to try her utmost to prove the strength of her inclination to pursue her studies in religion and Arabic literature in the land of the Prophets. Apart from this, the author also presents two other characters, Salwana and Iman, who are also two young Malaysian girls who bravely face the difficulties of studying in Syria in order to pursue religious studies there. The tenacity of the two 
young women as depicted in the novel can be seen in the following excerpt:

Iman menjeling. Salwana tidak habis-habis memerlinya. Dia ada alasan tersendiri untuk mengulangi pengajian peringkat sarjana muda yang diikuti di Universiti Malaya. Jika di Akademi Pengajian Islam dulu dia mengambil kursus al-Quran dan Hadith, di Damsyik, dia mahu menekuni ilmu dakwah pula.

(Iman glared at Salwana, who continuously made fun of her. She had her own reasons for taking another bachelor's degree, even though she had one from the University of Malaya. At the Academy of Islamic Studies, she had majored in Qur'an and hadith studies, here at Damascus she wanted to study Islamic da'wah.)

(Baromkeh Matamu di Mataku, 2009:152)

\section{Muslim Women and Careers}

Muslim women are involved in careers for economic contribution to the family. Women necessarily need to work outside the home because of the certain conditions in this day and age. Islam neither prohibits nor forces women's involvement in the working world. However, Muslim women need to limit themselves to jobs that are appropriate, always take care of themselves, not mix freely with men and obtain the permission of the father or husband. In fact, when women do go outside the home to work, they should not neglect their responsibilities to their husbands and children as this is an obligation that Islam places upon women. ${ }^{15}$ There are a number of reasons that support women to have careers, among them are:

1. women work to help improve the family finances;

2. many women have academic qualifications and work experience that should not go to waste. Therefore, working is a necessity so that the knowledge and talent they have can be channeled and put to good use;

3. women have the potential to help increase production and improve the country's economy.

Women are a necessary source of human capital for the country in several major sectors. ${ }^{16}$ This is also in line with the Qur'an which mentions the importance of women's involvement in the working world as long as it is not against Islamic provisions. For example, in surah al-Nisa', ayah 32 clearly states that every person regardless of gender will be rewarded for his 
or her efforts, if these are of religious merit. Allah SWT's decree concerning this can be translated as: "And do not wish for that by which Allah has made some of you exceed others. For men is a share of what they have earned, and for women is a share of what they have earned. And ask Allah of his bounty. Indeed Allah is ever, of all things, Knowing."

Surah an-Nisa', ayah 34 also mentions the role responsibility of women in the family, which is to reduce the burden of the husband if possible. This can be seen in the following translation of the meaning of this ayah "And due to the wives is similar to what is expected of them, according to what is reasonable. But the men have a degree over them (in responsibility and authority)." Thus, one can surmise that this ayah clearly shows the relationship between husbands and wives in strengthening the family finances is an important one and women may contribute with income from a career that the hold.

In connection with this, the novel Delima Ranting Senja shows that women with career are capable of contributing to the country. The depiction of Sofina as a journalist who constructs her research all over the world before reporting the news to the entire country shows the importance of women in dealing with issues that concern truth, justice and humanity, to be conveyed to women. Lolani, too, contributes through her research on women's issues together with Sofina and Datin Mariani. The idea that women are capable of upholding their honourable character as Muslim women even though their careers take them to far-off places can be seen in the following example:

"Ya Rabbi, jauh di bumi asing yang juga bumi ciptaan-Mu memberi hamba kesedaran ummah, keihsanan, kemuliaan; memang tidak banyak pintaku, tapi berilah hamba kekuatan iman, dengan sinar fikiran dan pelita hati, beri hamba kekuatan jasmani dan rohani untuk bergerak demi ibadah kepada-Mu. "

("Oh my Lord, being far from home on this Earth, which is your creation, has given me a sense of the meaning of ummah, of ihsan (excellence) and of nobleness. I ask for little except that you grant me strength of faith, and enlighten my heart and mind; grant me the physical and spiritual strength to be able to worship you.")

(Delima Ranting Senja, 2008:7)

Apart from this, the novel Episod Cinta di Tanah Hijrah also brings to the fore the importance of women with careers to the nation's economy. Through the character of Maisarah, who determinedly operates her goat 
farm in her village, it can be seen that knowledge, interest and hard work are the keys to success. Similarly, the character of Masitah, her twin sister, who, as a gynaecologist, gives aid to women in giving birth, shows that women doctors are important contributors in society. The role of the twins in this novel with their careers is to serve as examples other women as they never go against the regulations of Islam. Such is shown by the author in the example below:

"Aku perlu mengisi peluang yang kerajaan berikan, Sitah. Dalam al-Quran telah tertulis, negara perlu menyimpan makanan untuk tujuh tahun tetapi simpanan makanan negara kita hanya sembilan bulan. Aku akan masuk pertanian. Aku akan bantu negara."

("I have to take this opportunity that the goverment is offering, Sitah. In the Qur'an it says that a country should have food stores for seven years. But our country only has enough for nine months. I am going into agriculture. I will contribute to the nation in this way.")

(Episod Cinta di Tanah Hijrah, 2009:83)

"Tak ada yang mustahil dalam hidup ini selagi ada kemahuan, Mai. Tengok, dulu perubatan di negara kita daif sekali. Hanya mantera dan jampi serapah. Sekarang tidak lagi. Ada pelbagai kaedah perubahan yang matlamatnya sama-mencegah dan menyembuhkan."

("Nothing is impossible in this life while there is a will, Mai. Look, medical care used to be absolutely lacking in our country. People would read incantations and magic spells. There are various methods of treatment and they have the same aim - to prevent and to cure.")

(Episod Cinta di Tanah Hijrah, 2009:84)

The novel Lentera Mustika which focuses on the character of Ainur Mustika, who is a university lecturer, shows how important women are in this career for the development of education in the country. As someone who is highly qualified, being doctorate holder and an Associate Professor, Ainur Mustika can be considered as the axis to the development of quality education in the country. Ainur Mustika occupies a central position, as there is a need for outstanding academics who are capable of contributing their expertise and ideas in order to also produce quality graduates. Ainur Mustika's calibre as a highly-educated Muslim woman can be observed in the example below: 
Sekembali ke kampus, azan zuhur berkumandang di Masjid Universiti. Panggilan Tuhan itu segera ditunaikan. Dilepaskan segala bebanan, tekanan dan halangan dalam pengaduan kepada-Nya. Meresap setiap zat ketenangan yang dipinjamkan-Nya ke dalam jiwanya.

Usai solat, kotak e-mel segera disemak. Hampir separuh hari meninggalkan pejabat, Ainur Mustika menjangkakan puluhan pesanan masuk bertandang.

(On returning to the campus, the call to prayer could be heard from the university mosque. She quickly answered God's call. All her troubles and pressures were released in her submission to Him. Her soul became filled with tranquility bestowed on her by Him.

After performing her prayer, she quickly checked her email. Having been away from her office half a day, she expected a ton of new messages.)

(Lentera Mustika, 2009:60)

A similar idea is dealt with in Seteguh Fikrah Saleha where the main character, Saleha, is depicted as a successful cattle and goat farmer in Felda Bukit Ledang, even though she holds a university degree. Showing that she opts to become a farmer, just like Maisarah in Episod Cinta di Tanah Hijrah, is an example proving that women are capable of contributing to the nation's economy and become leaders in society, particularly to lead other women. An example to illustrate this is the following excerpt:

"Long Leman, saya bukannya cakap besar, saya ada Ijazah Perniagaan." Terpaksa. Aku terpaksa tarik kakinya dan jejakkan kakinya ke bumi. Tak ada cara lain untuk kukembalikan dia ke alam nyata daripada terus berkhayal. Aku mahu dia sedar dan tak menghina kerja-kerja intelektualku, yang kukerjakan bersungguh-sungguh. Dia perlu tahu dengan penuh rasa sedar, yang Ledang Enterprise adalah hasil kerja intelektualku bersama Hamzah. "Hamzah ada Pengurusan Ladang. Sekarang, kami ada ladang ternakan lembu di Kebun kelapa sawit dan sentang."

("Long Leman, I am not trying to boast when I say that I have a business degree." Forced. I was forced to pull his legs back down to Earth. There was no other way to bring him back to reality from his daydreams. I wanted him to realize, and not to belittle my academic qualifications, which I had obtained through hard work. He needed to know and fully realize that Ledang Enterprise was a result of mine and Hamzah's intellectual efforts. "Hamzah has a degree in Farm Management. Now, we have a cattle farm in an oil palm plantation.")

(Seteguh Fikrah Saleha, 2008:243) 
Further, the novel Baromkeh Matamu di Mataku also depicts women who have careers in order to support themselves financially. This is highlighted by the author by showing Fahda Nur diligently working as a computer operator in a shop run by a Syrian, to reduce her mother's financial burden back home. Even though she is working part time, Fahda Nur is able to do her job well. The following is an example from the novel to illustrate this point:

Kepalanya terasa berat. Dua malam matanya tidak dapat lelap kerana bekerja lebih masa sambil mengulang kaji pelajaran di pusat komputer itu. Suhu yang semakin rendah menyebabkan dia berasa lemah dan seperti mahu demam. Salwana mengejeknya sebagai roksun qosiyun kerana masih degil berjaga malam di Pusat Komputer Saadah walaupun kesihatannya merosot. Galau hatinya dek peperiksaan yang bakal menjelang tidak memungkinkan dia tidur lena di rumah. Lebih baiklah dia berjaga malam sambil mencari duit poket. Begitu dia memutuskan tindakan.

(Her head felt heavy. For two nights she had not been able to sleep because she had worked overtime at the shop while doing some revision of her studies at the same time. The dropping temperatures made her weaker and weaker, and she felt like she was falling ill. Salwana made fun of her, calling her roksun qosiyun, because of her stubbornness to work late at the Saadah Computer Centre even though her health was declining. Her nervousness as the examinations came nearer did not allow her to sleep soundly at home. It was better to work late and earn some extra money. This was the decision she had made.)

(Baromkeh Matamu di Mataku, 2008:242-43)

\section{Muslim Women and the Family}

The relationship between Muslim women and the family is a central one, since women are the ones who give birth to the next generation. In fact, in Islam, marriage is a bond that binds together men and women in a shared responsibility towards the household, with men as husbands and leaders, and women being the ones who are the continuers of human life on this Earth. This is mentioned in the Qur'an in surah an-Nisa', ayah 34, which outlines the importance of a woman's role in the family, in relationship to the standing of men: "Men are in charge of women by (right of) what Allah has given one over the other and what they spend (for maintenance) from their wealth." In conjunction with this, it can be said that Muslim women are responsible for their share in the family; a Muslim woman must carry on 
her relationship with her family because of the important status of family in Islam, and carry forth this relationship within the guidelines of the religion, even with her non-Muslim family members, since silaturrahim (bonds of affection) has a wide meaning, and it is necessary for a Muslim woman to keep up these bonds even if the others break them. ${ }^{17}$

The character Sofina in Delima Ranting Senja is thus shown to be a wife who is patient and accepting of her fate to be separated from her husband, Aby Redha, because of work. In this, she shows herself to be an examplary Muslim wife. Even though Sofina is depicted as someone who is active in managing her career as a journalist, as a wife, she is depicted as someone who is obedient and faithful. She is forced to accept that her marriage is being put to the test as she has to be separated from her husband due to the demands of his humanitarian work, and in this she is a good example for other women to strengthen the family relationship. The outstandingly noble characteristics of Sofina's personality can be seen in the following example:

Dan ada doa dan zikir yang menghambur merestui hubungan suami isteri. Tetapi selepas itu, si burung sudah tergesa ke meja sidang di perbatasan negara asing, semeja menemukan dua kumpulan yang saling berseteru. Si bunga kecil pula sudah tergesa berangkat terbang, untuk satu sidang lain lagi, ada laporan rasmi yang harus digarap jua. Dunia dengan pola yang semakin rabik, terlantun-lantun dalam rumah cinta dua pasangan aneh itu. Kau tidak kesal bukan?

(A little prayer and remembrance made marital relations possible. But right afterwards, the bird had to fly to the ends of the Earth to mediate between two warring tribes. The little flower herself had to leave to report on something official. In such a world, where the poles are unsteady, love itself becomes shaky. You don't regret it, do you?)

(Delima Ranting Senja, 2009:262)

In Episod Cinta di Tanah Hijrah the depiction of the close relationship between the twins Maisarah and Masitah, with their father and stepmother shows that they are faithful children who are capable of uniting a family. Although growing up in the village and having been raised by a stepmother after the death of their own, the twins never forget the sacrifices of both their parents. This clearly shows that Maisarah and Masitah fulfil the characteristics of qudwah hasanah. An example of this is seen here: 
"Umi tiada. Adam pun pergi. Yang tinggal hanya kita." Suaraku seakan merintih. "Kita hanya dua beradik." Ada kerinduan menjentik hatiku.

"Kita masih beruntung. Kita ada ayah. Mak ibu sayang kita seperti ibu sendiri." Suara Maisarah lembut dan perlahan masuk ke cuping telingaku.

("Umi is gone. So is Adam. We are the only ones left." My voice sounded a little whiny. "There's only two of us siblings left." A little longing tugged at my heart.

"We are still fortunate. We have dad. Mummy loves us like her own children." Maisarah's voice came softly to my ears.)

(Episod Cinta di Tanah Hijrah, 2009:85)

In Lentera Mustika, the strong family ties that Ainur Mustika keeps up with both her cousin and her aunt make her an example of a good Muslim woman. Even though she has achieved a high position in her career, Ainur Mustika does not ignore the blood ties that bind her to her relatives in the village, and she often visits her elderly aunt and uncle there. Similarly, where marriage is concerned, Ainur Mustika never opposes her aunt and uncle when Emir Johan comes to ask for her hand in marriage. Thus, Ainur's behaviour is that of an examplary Muslim woman. The relationship between Ainur Mustika and her relatives is depicted in the following example from the novel:

Sewaktu Ainur Mustika hendak meninggalkan jendela itu, dia terpandang pak longnya datang bersama-sama dua tiga orang lagi jemaah surau yang datang menolong. Kata pak longnya pagi tadi, kalau boleh mereka semua mahu menyudahkan penanggah di rumah sebelah-rumah pusaka Ainur Mustika itu. Khemah tetamu sudah dipesan dan tidak perlu dirisaukan lagi.

(When Ainur Mustika was about to leave the window, she saw her eldest uncle arriving, accompanied by a few other men whom he often prayed with at the surau. Her uncle had told her that morning that, if possible, they wanted to finalize everything about the helpers at the wedding in the house next door-Ainur's ancestral home. The tents had been rented and she need not be concerned about these anymore.

(Lentera Mustika, 2009:299)

A similar situation is put forth in Seteguh Fikrah Saleha, where Saleha has the utmost respect for her mother and grandfather, even though the two elderly people are incapable of contributing anything to the family anymore. Saleha's readiness to take into consideration her mother's point of view in 
everything she does shows that this young woman is a religious child. Even though she is capable and shows it by being successful in her career, Saleha does not abandon her folks in the village and continues to have a close relationship with them. The author depicts the close family relationship in such as the following:

Aku peluk dan cium pipi dan tangan emak memohon restu. Emak kucup dahiku dan betulkan kerongsang tudung di bahu kiriku. Emak betulkan letak bahu baju kurung sutera Korea biru laut berbunga kecil, hitam putih yang emak gosokkan semalam dan menyuruh kupakai pagi ini. Hamzah turut peluk dan cium pipi emak.

(I hugged mother, and kissed her cheeks and hands to ask her blessings. Mother kissed my forehead and straightened the brooch that fixed my headscarf on my left shoulder. She straightened the blouse of my sky-blue Korean silk baju kurung with the little black-and-white fowers that she had ironed and asked me to don that morning. Hamzah, too, hugged and kissed mother on the cheeks.)

(Seteguh Fikrah Saleha, 2008:202)

The novel Baromkeh Matamu di Mataku also presents a close relationship between mother and daughter, even though the mother is unable to offer financial assistance to her daughter overseas. While in Syria, Fahda Nur often contacts her mother, and worries about how she is doing, as she is a single parent. Her sensitivity towards her mother's situation and her determination to uphold her mother's good name and fulfilling what she has been entrusted with by her mother clearly make Fahda Nur a Muslim woman who possesses the characteristics of qudwah hasanah. The novel presents the mother-daughter relationship as a very close one, as can be seen here:

Dalam khayalnya, dia memeluk erat tubuh ibu, bagai tidak mahu dilepaskan lagi. Ibulah payung kehidupannya dan Masrur. Dia tidak mahu ibu bersusah lagi. Sekiranya ada rezeki dia menjejak lagi bumi Damsyik, maka datangnya akan bersama ibu dan Masrur. Begitu janji Fahda Nur.

(In her dream, she hugged her mother tightly, as if not wanting to let her go. Mother was both hers and Masrur's protector in life. She did not want her mother to suffer again. If by divine providence she were once again to set foot in Damascus, she would do so with Mother and Masrur. This was Fahda Nur's promise.)

(Baromkeh Matamu di Mataku, 2008:308-09) 


\section{Muslim Women and Society}

The relationship with society occupies a position of priority for a Muslim woman. This is because women are considered the main movers and key figures in developing persons of good quality. For this, Muslim women themselves must display an examplary character and admirable personality. It is of great importance for women to have an honourable demeanour as this will unite society as the khaira' ummah (best community) because by upholding the value of amar makruf nahi mungkar (enjoining good and forbidding evil), the relationship between people and Allah SWT will work smoothly and in a controlled manner. In fact this is in line with the idea contained in surah Ali 'Imran, ayah 104, whose meaning can be rendered as: "And let there be (arising) from you a nation inviting to (all that is) good, enjoining what is right and forbidding what is wrong, and those will be the successful." It can be surmised that Muslim women play a role in determining the form a society takes, and its pattern of thought, taking into consideration a view of positive values that become its unique basis.

Further, Sofina, in the novel Delima Ranting Senja, is depicted as someone who has a strong sense of initiative and commitment to channel useful information to the community. As a media person dealing with culture, Sofina deals a lot with people from all over the world, and thus exemplifies a harmonious relationship that brings about an ummah (community) capable of moving forward. The author's observations concerning relationships in society are recorded below:

Bukit Bangi sudah mula meriah. Sofina bergabung dengan Seri dan Uda Yos. Isu hak asasi dan kemanusiaan sudah bertindan lapis dengan isu pembunuhan dan pagar tinggi Israel. Aqran sudah mengumpul senarai nama anak-anak mangsa kesan perang tidak selesai. Tetapi Fina sudah lelah dengan isu perang nun jauh di sana, dia sudah memilih data yang terdekat dengan pembangunan kota raya. Berlapis-lapis taman baru wujud, bukit dan gunung gondola, dan warisan ibu pun digondoli, dilupuskan dengan janji bayaran ganti rugi, tetapi siapakah yang masih dapat bertahan kala kampung-kampung sudah ditenggelami banjir tanah merah sehingga bangunan rumah kampung dan sekolah di tepi jalan sepanjang kota yang baru dibina menjadi merah kelabu.

(Bangi Hill was coming alive. Sofina joined up with Seri and Uda Yos. The issue of human and basic rights had become combined with the issue of killing and Israel's Separation Barrier. Aqran had already put together a list of names of children who were victims of this never-ending war. But Fina had 
tired of the issue of that war in a faraway country, and was already selecting data about city development from closer to home. New housing estates were mushrooming, and hills and mountains were being stripped of their trees. Even mother's ancestral lands had been bulldozed, with the promise of compensation. But who could stay on when the villages were being flooded with red mud, causing the houses and the school that flanked the road, which had been newly built, to turn grey?)

(Delima Ranting Senja, 2008:403-04)

Even the character Masitah, in Episod Cinta di Tanah Hijrah, an example of a woman and her relationship with society, in that because of her services as a doctor of gynaecology is especially valuable to women. The depiction of Masitah as a gynaecologist and her great contributions to society can be seen in the following example:

"Ketentuan pada Tuhan. Ikhtiar tidak menjanjikan beberapa peratus kejayaan. Segalanya mungkin pada kuasa Tuhan." Aku menyuntikkan kesedaran. ”Segala yang tidak baik yang bertulis semenjak azali boleh ditangkal dengan doa. Kita berserah kepada Allah. Hanya pada Dia kita berharap dan meminta. Saya hanya membantu, puan." Aku insaf, sehebat mana pun manusia, masih bergantung harap pada Maha Pencipta.

("Fate lies in the hands of God. Effort alone does not guarantee success. Everything is in God's power." I attempted to insert some realization. "Everything bad that has been pre-ordained may be changed through making do'a. We must submit to Allah. It is only to Him that we can turn and ask for help. I am only helping, madam." I myself realized that no matter how great people were, they still depended on Allah, the Great Creator.)

(Episod Cinta di Tanah Hijrah, 2009:60)

In Lentera Mustika, Ainur Mustika's relationship with society is realized through her position as a university lecturer, through which she is able to teach young people to love knowledge, especially Malay poetry, which may reinforce their appreciation of their country and cultural heritage. How Ainur Mustika behaves as a campus educator is depicted in the following example:

Dia kembali menumpu pada kuliahnya yang akan berlangsung dalam masa 15 minit lagi. Beg khusus untuk mata pelajaran Puisi Tradisional terus dicapai. Bagi memudahkan tugas memberi kuliah, dia telah mengasingkan satu beg bagi setiap mata pelajaran. 
MALAY LITERATURE VOLUME 26 NUMBER 2

(She once again concentrated on the lecture she had to give 15 minutes. She reached for the briefcase for the subject Traditional Poetry. To make her work easier, she had separate briefcases for each subject.)

(Lentera Cinta Mustika, 2009:280)

Similarly, in Seteguh Fikrah Saleha, Saleha, with great love for her vilage folk, provides them the opportunity to contribute to their fatherland through her farm. How Saleha keenly makes an effort to provide service to the village folk can be seen in the following:

Aku tunjukkan seratus ekor lembu-lembu di kandang di belakang kami. Tunjukkan bangsal meracik makanan lembu. Dia terlopong apabila aku jelaskan bahawa kami merancang dirikan pusat pembuatan makanan ternakan. Pihak pengurusan tanah rancangan sudah meluluskan sepuluh ekar tanah terbiar bagi projek yang menelan belanja hampir enam ratus ribu ringgit itu.

(I showed the one hundred cows in the stable behind us. I showed the barn where we prepared the feed. When I explained that we were planning to establish a centre for making farm animal feed, it was met with a gape. The management of the land scheme had already approved ten acres of unused land for the project that would cost almost six hundred thousand ringgit.)

(Seteguh Fikrah Saleha, 2009:233)

Meanwhile, Fahda Nur in Baromkeh Matamu di Mataku is an example that shows that a young person can foster a harmonious relationship with the local populace through her friendship with Anisah Muna's family, Ummu Huzaifah, Jabir, Marwa and other Arabs. An example of Fahda Nur's friendship with the Arab people is seen in the following excerpt:

"Aku datang ini kerana ingin meminta maaf andai sepanjang ukhuwah kita, aku menyinggung perasaanmu dengan cara yang tidak sepatutnya," tutur Fahda Nur dengan lembut. Dia tidak mahu menangis lagi. Itu nekadnya. Dia datang untuk mengucapkan terima kasih dan memohon maaf daripada perempuan yang dianggap seperti ibu itu, walaupun dia belum pasti bila tarikh kepulangannya ke tanah air.

("I am coming to apologize to you, if, in the course of our friendship, I have hurt your feelings in any way," said Fahda Nur softly. She did not want to cry anymore. She had made up her mind. She came to say her thanks and to 
ask forgiveness from the woman who was like a mother to her, although she was not sure when she would return home to her country.)

(Baromkeh Matamu di Mataku, 2008:283)

\section{CONCLUSION}

Based on the above analysis of recently-published Malay novels written by women authors, it can be seen that the concept of qudwah hasanah is clearly present in each of the novels, in line with the requirements of Islam. Although the characters depicted may only represent a certain group of womenwomen with a certain social status, education and career-such writings may contribute to the emergence of similar works that are beneficial to the ummah. In general, local women writers, regardless of age and education, want to raise the status of Muslim women, and place them at their rightful position in which they can serve as examples for readers.

\section{NOTES}

1. This view has been stated by Shahrom Hussain, and has been further explored by Rosnah Baharuddin in her book. Please refer to Rosnah Baharuddin, 2003. Wacana Wanita Melayu dan Sastera. Bangi: Universiti Kebangsaan Malaysia, p. 24.

2. Among others, one could refer to Khamsiah Ahmad, Wanita Islam, 1981. Singapore: Pustaka Nasional Pte Ltd; Hamka, Kedudukan Perempuan dalam Islam, 1996. Jakarta: Pustaka Panjimas; Faisal Hj. Othman, 1996. Kedudukan dan Peranan Wanita dalam Islam. Kuala Lumpur: Utusan Publications \& Distributors Sdn. Bhd; and Andek Masnah Andek Kelawa, 2001. Kepimpinan Wanita dalam Islam - Kedudukannya dalam Syariah. Bangi: Penerbit UKM.

3. This has been detailed in Afzalur Rahman, 1994, Ensiklopedia Sirah-Peranan Wanita Islam (transl.), Kuala Lumpur: Dewan Bahasa dan Pustaka, p. 524-25.

4. The same has been touched upon in other research. See Kamariah Kamarudin, 2006, "Martabat Wanita Melayu Islam dalam Pelestarian dan Pembangunan Peradaban Insan: Satu Analisis Berdasarkan Novel Sudara dan Surat-surat Perempuan Johor" in Prosiding Persidangan Antarabangsa Pengajian Melayu 2006, Kuala Lumpur: Penerbit Akademi Pengajian Melayu, Universiti Malaya, p. 158.

5. Al-Zamakhshari, in his Al-Kashshaf, interprets the meaning of uswah in surah al-Ahzab, ayah 21 by saying that uswah synonymous with qudwah. Similarly, Imam al-Qurtubi, in his interpretation, Jami' Ahkam al-Quran, gives the same explantion for the meaning of the word. For further explanation, refer to al-Zamakhshari's Al-Kashshaf, and Imam Al-Qurtibis' Jami' Ahkam al-Quran.

6. The term qudwah is mentioned in surah al-Ahzab, ayah 21 and surah al-Mumtahanah, ayah 4 and 6.

7. This has been explained further in Asiah 'Ali, 1999. Muslimah, Pendidikan, Kekeluargaan 


\section{MALAY LITERATURE VOLUME 26 NUMBER 2}

dan Perjuangan. Kuala Lumpur: Penerbitan Muttaqin Sdn. Bhd, p. 28-29

8. Ibid, p. 66-69.

9. This is also touched upon in Khalijah Mohd Salleh, 1985. "Women, Her Islamic Personality, Her Future Development for the Ummah" in Women In Development.Kuala Lumpur: Institut Kajian Dasar, p. 19-34.

10. Further explanation concerning this, please refer to Muhammad Ali Al-Hashimi, 2006, Kepribadian Wanita Muslimah, (transl.). Saudi Arabia: International Islamic Publishing House, p. 24-150.

11. "Whoever does righteousness, whether male or female, while he is a believer - We will surely cause him to live a good life, and We will surely give them their reward (in the Hereafter) according to the best of what they used to do.", Al-Qur'an dan terjemahnya, 1419H, Mujamma' al-Malik Fahd li Tiba' at al-Mushhaf al-Syarif Madinah Munawwarah, Ministry of Islamic Matters, Waqf, Da'wah and Irshad, Saudi Arabian Government, p. 417.

12. "O mankind, fear your Lord, who created you from one soul and created from it its mate and dispersed from both of them many men and women. And fear Allah, through whom you ask one another, and the wombs. Indeed Allah is ever, over you, an Observer.", ibid, p. 114

13. Surah al-Hujuraat, ayah 13 can be translated as meaning: "O mankind, indeed We have created you from male and female and made you peoples and tribes that you may know one another. Indeed, the most noble of you in the sight of Allah is the most righteous of you. Indeed, Allah is Knowing and Acquainted.”, ibid, p. 847.

14. For a detailed explanation, see op.cit, p. 153-96.

15. Baterah Alias and Che Zarrina Sa'ari, 2006. Islam dan Emansipasi Wanita. Kuala Lumpur: Penerbitan Universiti Malaya, p. 107.

16. Detailed explanation, please see Baterah Alias and Che Zarrina Sa'ari, ibid, p. 109.

17. This has been further explained by Muhammad Ali Al-Hashimi, please see op.cit, p. 336-54.

\section{REFERENCES}

Al-Qur'an dan terjemahnya (Al-Qur'an and its Translation), 1419H. Mujamma'alMalik Fahd li Tiba' at al-Mushhaf al-Syarif Madinah Munawwarah. Ministry of Islamic Matters, Waqf, Da'wah and Irshad, Saudi Arabian Government. Afzalur Rahman, 1994. Ensiklopedia Sirah-Peranan Wanita Islam (trans1.), Kuala Lumpur: Dewan Bahasa dan Pustaka.

Amaruszati Noor Rahim, 2009. Episod Cinta di Tanah Hijrah. Kuala Lumpur: Dewan Bahasa dan Pustaka.

Aminah Mokhtar, 2008. Seteguh Fikrah Saleha. Kuala Lumpur: PTS Publications Sdn. Bhd.

Andek Masnah Andek Kelawa, 2001. Kepimpinan Wanita dalam Islam-Kedudukannya dalam Syariah. Bangi: Penerbit UKM.

Asiah 'Ali, 1999. Muslimah, Pendidikan, Kekeluargaan dan Perjuangan. Kuala 
Lumpur: Penerbitan Muttaqin Sdn. Bhd.

Baterah Alias and Che Zarrina Sa'ari, 2006. Islam dan Emansipasi Wanita. Kuala Lumpur: Penerbitan Universiti Malaya.

Faisal Hj. Othman, 1996. Kedudukan dan Peranan Wanita dalam Islam. Kuala Lumpur: Utusan Publications \& Distributors Sdn. Bhd.

Hamka, 1996. Kedudukan Perempuan Dalam Islam. Jakarta: Pustaka Panjimas.

Kamariah Kamarudin, 2006. "Martabat Wanita Melayu Islam dalam Pelestarian dan Pembangunan Peradaban Insan: Satu Analisis Berdasarkan Novel Sudara dan Surat-surat Perempuan Johor" in Prosiding Persidangan Antarabangsa Pengajian Melayu 2006. Kuala Lumpur: Penerbit Akademi Pengajian Melayu, Universiti Malaya.

Khalijah Mohd Salleh, 1985. "Woman, Her Islamic Personality, Her Future Development for the Ummah" in Women In Development. Kuala Lumpur: Institut Kajian Dasar.

Khamsiah Ahmad, 1981. Wanita Islam. Singapore: Pustaka Nasional Pte. Ltd.

Muhammad Ali Al-Hashimi, 2006. Kepribadian Wanita Muslimah (transl.). Saudi Arabia: International Islamic Publishing House.

Nisah Haron, 2009. Lentera Mustika. Kuala Lumpur: PTS Milenia Sdn. Bhd.

Rosnah Baharuddin, 2003. Wacana Wanita Melayu dan Sastera. Bangi: Universiti Kebangsaan Malaysia.

Siti Zainon Ismail, 2009. Delima Ranting Senja. Kuala Lumpur: Utusan Publisher. Ummu Hani Abu Hassan, 2008. Baramkoteh Matamu di Mataku. Kuala Lumpur: Universiti Publication \& Distributors.

(Translated by Tanja Jonid) 